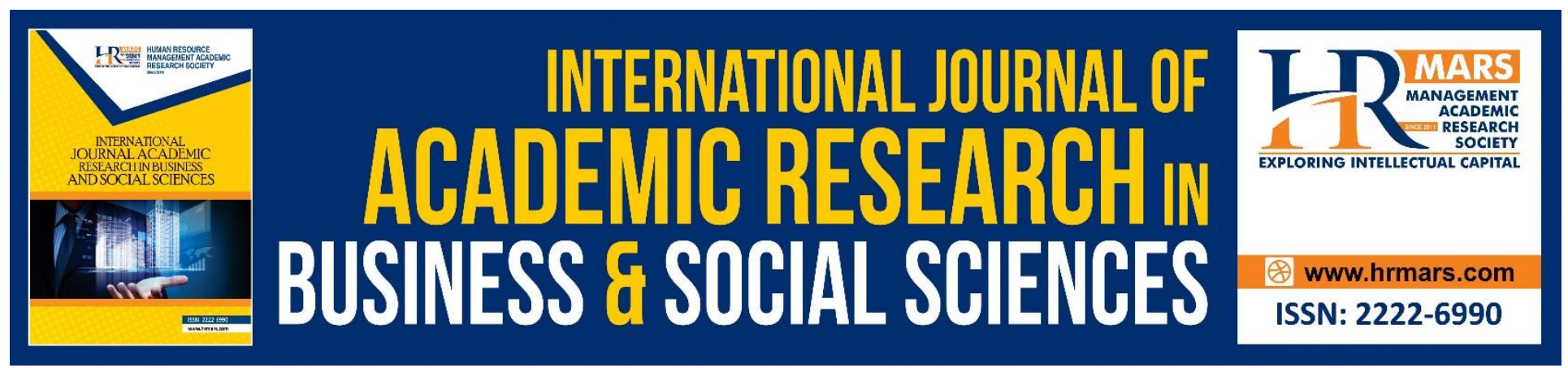

\title{
The Needs of Teaching English through Effective Interaction for Early Childhood Teachers
}

Siti Hamira Md Ngajib, Mazlina Che Mustafa, Zainiah Mohamed Isa, Ainon Omar, Zaharah Osman, Mohammad Aziz Shah bin Mohamed Arip, Noor Aini Ahmad

To Link this Article: http://dx.doi.org/10.6007/IJARBSS/v8-i11/5376 DOI: $10.6007 /$ IJARBSS/v8-i11/5376

Received: 03 Nov 2018, Revised: 24 Nov 2018, Accepted: 03 Dec 2018

Published Online: 09 Dec 2018

In-Text Citation: (Ngajib et al., 2018)

To Cite this Article: Ngajib, S. H. M., Mustafa, M. C., Isa, Z. M., Omar, A., Osman, Z., Arip, M. A. S. bin M., \& Ahmad, N. A. (2018). The Needs of Teaching English through Effective Interaction for Early Childhood Teachers. International Journal of Academic Research in Business and Social Sciences, 8(11), 1877-1887.

\section{Copyright: (C) 2018 The Author(s)}

Published by Human Resource Management Academic Research Society (www.hrmars.com)

This article is published under the Creative Commons Attribution (CC BY 4.0) license. Anyone may reproduce, distribute, translate and create derivative works of this article (for both commercial and non-commercial purposes), subject to full attribution to the original publication and authors. The full terms of this license may be seen

at: http://creativecommons.org/licences/by/4.0/legalcode

Vol. 8, No. 11, 2018, Pg. 1877 - 1887

Full Terms \& Conditions of access and use can be found at http://hrmars.com/index.php/pages/detail/publication-ethics 


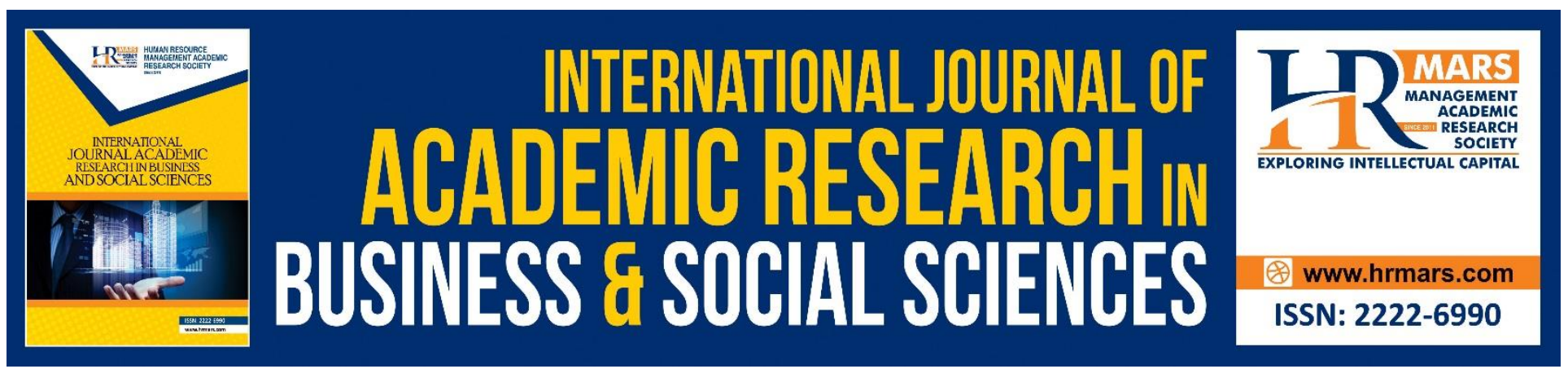

\title{
The Needs of Teaching English through Effective Interaction for Early Childhood Teachers
}

\section{Siti Hamira Md Ngajib, Mazlina Che Mustafa, Zainiah Mohamed Isa, Ainon Omar, Zaharah Osman, Mohammad Aziz Shah bin Mohamed Arip, Noor Aini Ahmad}

National Child Development Research Centre (NCDRC), Sultan Idris Education University (UPSI), Malaysia.

\begin{abstract}
This study explores the early childhood teachers' needs in teaching English through effective interaction with young children. Qualitative approach and case study design have been adopted for this study involving six qualified early childhood teachers. Research methods include pre- and postobservation interviews, observations and field notes. Observation were carried out two times for each teacher during free play sessions, meal times, circle times, teaching and learning sessions as well as the storytelling sessions. Thematic analysis is used to analyse the data deductively. The themes emerged are organised to answer the research question. In order to interact effectively in English with the children, the teachers need to have interest in the language and develop selfconfidence. Positive English dominant environment is also crucial for the teachers to interact with their colleagues and children in English. In conclusion, it is important to analyse the early childhood education teachers' needs to ensure the effectiveness of English interaction between them and with the children. The implications of this study highlight that early childhood education teachers need to go for continuous professional training on teaching English to children and there should be monitoring on the use of English as an effective interactional tool.

Keywords: Early Childhood Teachers' Needs, Teaching English, Effective Interaction, Young Children, ESL.
\end{abstract}

\section{Introduction}

Early childhood education teachers play important roles on producing bilingual citizens in early years particularly for teaching English through effective interaction. The purpose of this study is to investigate early childhood teachers' needs for teaching English through effective interaction with young children. Interaction is a communication pattern that occurs between a person and another which leads to behaviour (Ellis, 1999). Effective interaction in SLA occurs when people give respond and feedback that facilitate the second language acquisition. In this context, effective interaction 
occurs when teachers get response from the children and they could give appropriate feedback to facilitate the second language acquisition. There is a critical need to investigate the needs of EC teachers because they are not professionally trained to teach English as a second language as early childhood teachers have low proficiency in English, cannot speak fluently and have no self-confidence to speak in English (Rohaty, 2013). According to the conference on Teaching English to Young Learners organised at Bangalore (Enever, Moon, \& Raman, 2009), it has been highlighted that problems arise when teachers are not well prepared to teach young learners due to insufficient trainings for the teachers and employers recruiting less qualified and incompetent English language teachers. In addition, English is not ECE teachers' field of specialisation, but they are required to teach English to young learners (Chodijah, 2008; Enever et. al, 2009). In Malaysian context, there could be a similar problem which needs further investigation in the context of ECE teachers' preparation to teach English.

Teachers are responsible for creating friendly and meaningful teaching and learning atmosphere for the children to acquire English effectively. Thus, teachers should provide children with a supportive environment which support their English acquistion significantly in terms of motivation and learning environment. Although formal teaching does not provide a wide range of roles in second language learning, it provides comprehensible language input to the young learners (Wang, 2015). The scaffolding strategy of teaching techniques is to help the children to acquire second language through interaction. Few studies have investigated the scaffolding strategies with children. Mohd Sidek (2011), through his experimental study, manipulated the interactions with the child to determine the interactions' effect of scaffolding on the child's syntax development. An action research done by Brierly (2003), she finds out that to increase interaction opportunities between teacher and children, it was important to follow children's interest to get engage in interaction and thus create more natural opportunities for interaction. Early children education teachers need to encourage ELL to be active participants in interaction and develop their cognitive development by consider allocating some times for scaffolding ELL's oral language in small group activities. Furthermore, Van Canh \& Renandya (2017) identified that teachers' language proficiency could influence their language use during the interaction with the ELLs and this highlight the importance of their language proficiency.

The most important factor in the amount of language acquired by a learner is the amount of comprehensible input to which that learner is exposed (Krashen, 1982). Comprehensible input, as Krashen characterised, shares both "a point of commonality and a point of difference" with the ZPD (DeVillar, 1991, p. 23). There are two constructs that are shared by comprehensible input and ZPD; first, advancement is achievable as long as that language input is made comprehensible to the learner by an adult or more capable peer, and second, both constructs emphasise the need of being responsive to the learners' perceived needs (DeVillar, 1991). Negotiation of meaning happens to be labelled differently by different scholars, such as conversational adjustment and interactional modification (Pica, 1994). In other words, these modifications of meaning are commonly regarded as interactional adjustments during negotiation for meaning to achieve comprehensibility of input (Mackey, Abbuhl, \& Gass, 2012). Different task types elicit different kinds of interaction from the learners, and how the participants approached and processed the tasks shaped the kind of learner interactions they generated (Hazleena and Abd Razak, 2013). 
Teachers need to be competent in English language knowledge before they start teaching children. Highlight on the benefits of effective interaction to learn English. Teachers need to identify their own needs to teach English through effective interaction. Chlapana and Tafa (2014) findings in their study raised some concerns regarding on how teachers would teach English to children if they themselves were not competent in the instructions.

\section{Research question}

What are the needs of early childhood teachers to teach English through effective interaction with young children?

\section{Method}

\section{Participants}

Six early childhood teachers were selected through purposive sampling from an early childhood centre in Tanjung Malim. The centre was selected as the site of the study due to distance proximity and they teach the children from infant to six years old. All the participants were female they were qualified early childhood education teachers who teach English as a second language to the children. Most of the teachers had at least a bachelor's degree in early childhood education and had experiences in teaching English to young children. The participation was voluntary. All participants involved were provided with informed consent. In this study, all names are concealed by using pseudonyms.

\section{Non participant Observation}

In this study, the researcher observed interactions between teachers and children in English during daily routines and teaching and learning session. Non-participant observation took place in the study because of the data gathering strategy used through previous study, primary data was collected without interrupting any of the participants' activity (Dholakia \& Zhang, 2004). Unobtrusive measures had been taken to ensure that the participants showing all their spontaneous action in natural surroundings. The researcher simply record what was seen with video recorder and also wrote field notes on what were the teachers' needs to enhance the effectiveness of their interaction in English with the children. The observations have been done twice of each participant within two months.

\section{Interview}

Semi-structured interview was conducted by the researcher to each of the participant twice which are before and after the observation process. Pre-observation interview was done prior to get the insight of teachers' experiences, perspectives on their needs needed in teaching English with young children. Whilst post-observation interviews aimed to reflect and gain reasons of any teachers' action during their interactions with the children while teaching English. The researcher records the interview by using voice recorder to minimise the uneasiness of the participants as they avoid being video recorded. The ability of the audio recorder in storing the interview session as well as being stimulated recall tool, ensures the effectiveness in data gathering. 


\section{Data gathering method}

Three steps were taken to elicit data in this study. Each participant was subjected to a pre-observation interview, a videotape observation and post-observation interview. The researcher interviews the participants before and after observations to ensure rich interpretation of the data. The observation does not only focus on the lesson periods, but also collects data from routines such as circle times, meal times, storytelling and free play sessions. The semi-structured interview was conducted and interview protocol was developed to assist the interview process. Observation was done by implementing non-participant observation, recording and field notes were also included. Nonintrusive observation was done to maintain the natural setting and environment of the teaching and learning during English were used between children and early childhood teacher.

\section{Data Analysis}

This study employs thematic analysis to analyse the data. Thematic analysis aims to analyse both explicit and implicit ideas of the participants' responses and the data will be sorted into several themes (Guest, MacQueen and Namey, 2011). The researcher at first transcribes the interviews and starts the analysis with coding the repetitive statements from the teachers. The themes emerged after the related topics are assembled.

\section{Teachers' interest}

During pre-observation interviews, the participants were asked about their perceptions towards English.

"So macam saya, akak (Cikgu sendiri) sendiri kan, pengalaman akak, err OK akak memang tadika di tadika KEMAS. Yang memang cikgunya ajar bahasa Melayu sahaja. K, so bila, daripada awal kan kita tak dapat pendedahan English daripada. . mak ayah kita pun orang biasa kan, so jarang cakap bahasa Inggeris dengan kita. So lepas tu, tak minat tu sampai ke sekolah menengah. Tak minat sangat bahasa Inggeris." (from my experiences, I was attending tadika KEMAS. The teachers only taught in Malay. OK, so from the earlier we did not receive English language exposure... My parents did not speak English with us. So, and then.. I have no interest until I enrolled in high school. I'm not fond of English language).

Teachers' interest is related to teachers' performance in producing interaction with children in English. Teachers who have least interest in English produce least of English utterance frequency with children. They would have interaction but in their first language. Language mixing occurred while interacting with the interaction. It is shown in the observation recorded, they are using both Malay and English language in the classroom. Sometimes when the teachers could not find the right word to say, they would use Malay word instead. T4 said that she did not like English since she was at school. 
INTERNATIONAL JOURNAL OF ACADEMIC RESEARCH IN BUSINESS AND SOCIAL SCIENCES

Vol. 8, No. 11, Nov, 2018, E-ISSN: 2222-6990 @ 2018 HRMARS

\section{Teachers' self-confidence}

When T4 dealt with ELLs' limited proficiency, she was in doubt of her ability to speak English with the children.

"...kita jadi macam bila nak guna fully English tu jadi macam tak confident tu kadang-kadang." (Sometimes I become not confident when it's time to use full English with children)

T4's lack of confidence was noticed when she did not use English appropriately when interacting with children in English. She directly translated English to Malay language. She mixed up both languages while delivering instructions to the children. It was apparent in the observation that the teacher could hardly get feedback from the children in English. In addition, the teacher doubted that the children could understand what she was saying and feared that the children could not answer her questions and follow her instructions.

T4's lack of confidence is supported in a post-observation interview when she said there was no feedback from the children when she tried to speak English with them. Usually the children ignored her when she tried to speak in English with the children. Thus, she mainly used Malay in delivering instructions.

\section{Teachers' working environment}

In the pre-observation interview, most of the teachers said that the practice of English language is not a culture among their colleagues.

"Dengan kawan-kawan tu kalau macam sembang.. nak .. tapi tak lah sembang yang betulbetul serius, sangat pun tapi kadang-kadang minta tolong diorang betulkan balik macam mana kita nak cakap cara yang betul tu. Kadang-kadang diorang ni pun bagus juga, diorang tolong kita kan. Hat yang pandai-pandai tu diorang betulkan balik lah bahasa Inggeris kita." (When we were having conversation in English, it would never be full English. But if we are having conversation, my colleague will correct me if I'm use the words incorrect. The one who better English will always help correcting my English)

T4 said that during the meeting held with the superiors, the teachers were quiet when they have to respond in English. She said that she also became a quiet person when she had to speak English. She was afraid of making mistakes while talking in English.

Lack of interest and low self-confidence are two of the Affective Filters (1982) that need to be removed. Teachers need to be interested with the English language in order to use it while interacting with the children. Besides, self-confidence is important for the teachers as it is acts as courage to use English in their interaction with the children. Furthermore, teachers need working environment to use English effectively a supportive to talk English among colleagues and with the children.

\section{Discussions}

One of the challenges that the teachers faced was their low self-confidence to use English. Teachers could not interact well in English with the children because they are doubtful of their ability when 
using English. Majority of the teachers have been observed to use the same sentences of instructions several situation such as instruction for queuing, question for the children's feelings and also when asking the children to sit down properly. For instance, the teachers will ask the question of 'how do you feel today?'

Teachers' self-confidence is considered as one of the needs that arose from the findings. Krashen's Affective Filter Hypothesis (1982) claimed that, if one could not overcome the inner crisis on lacking self-confidence, attitude, anxiety and motivation, he or she will have hard time to enhance their language development.

Identifying the teachers' needs is important in order to support the teachers to teach English to the children through effective interaction. Making interaction effective were challenging when the teachers struggle to interact with the children. The teachers realise that they have low English proficiency and do not want to misguide the children. Fear of delivering the unintentional mistakes makes the teachers inhibit themselves to interact in English with young children.

Teachers must overcome their low self-confidence to make their interaction effective with the children. Krashen's Affective Filter hypothesis (1982) highlighted that the teachers who have lack of confidence tend to be extremely fearful, timid and reluctant to use English regularly. This situation can be seen when the teachers frequently prefer to use home language to interact with the children. Although the children might not fully understand what the teachers are saying, but the teachers need to facilitate their understanding by using non-verbal such as gestures, body language, and also physical actions. These strategies provide comprehensible input for the children as they acquire English although they may not respond. The children have the silent period in which they are actually absorbing as much as they can to understand the language especially when they have limited range of vocabulary (Bligh, 2011). Teachers also have to set in their mind that children who acquire the second language will have their silent period. Teachers need to bear that in some of the children will not respond to the teacher's talk because they have insufficient vocabulary to speak. In addition, the children also probably develop their interest in the language and self-confidence to respond to the teachers' talk.

Furthermore, the teachers also need to create an English dominant environment to facilitate the SLA of the children. Mazlina (2015) claims that English dominant environment could facilitate the English language learners (ELLs) to acquire English. The children also need English speaking exposure in a supportive environment to encourage them to use English in their interaction with teachers as well as with their peers. According to the Tsang (2017), the teachers who cannot speak English well, will not be convincing enough to teach English to student. Thus, it is important for the teachers to get support from their working environment to improve speaking skill.

The teachers are comfortable to use Malay as the language of interactions and instructions because the children could respond to Malay better than English at a certain time. For example, the teachers will only use the same instruction asking the children to make a straight line. The researcher started to wonder if the children could understand the words if the teachers use it in a different context. It is because the children acquire English by listening to the same word or phrases repeatedly used in different situations. When the teachers are interacting with each other in English, they could hear the words are being used in a different situation not only in selected activities in class. 


\section{Limitations}

Several limitations exist in this study because it only focuses on teachers' needs in teaching English through effective interaction with young children. The context of this study is early childhood education and second language acquisition. The study is adopts a qualitative approach. This case study design only selects six qualified early childhood teachers through purposive sampling. Samples are taken from only one early childhood centre and they teach English through interaction as well as through teaching and learning session with children age ranged from four to six (4 - 6) years old. The participants of this study are qualified early childhood teachers who underwent pre-service training and learn teaching English for young children courses at university level. Besides, this study does not measure the early childhood teachers' English competency to teach English as a second language to the children.

\section{Implications}

In order to have good quality of early childhood education teachers who can teach English using interaction strategy, there is a need to have a policy for continuous professional development for the teachers. Most of the teachers' development plan is mainly for the secondary school. However, there was not enough the professional development for early childhood education teachers. Early childhood education teachers should be trained continuously to improve their English proficiency and competency. This is important as the child's learning technique is different from adult's learning style. The teachers need to have exposure on how to support the children's English acquisition through effective interaction.

Moreover, the teachers also need monitoring to ensure the use of English for 600 minutes in a week for the Malay medium early childhood centre and 400 minutes in a week for the other languages used for medium of communication (Kementerian Pendidikan Malaysia, 2016). As the minimum of hours embedded in the National Standard of Preschool Curriculum, the teachers might need a monitoring person who can be an appointed officer who can provide feedback and support for the teachers to use English effectively in interaction with the children.

\section{Recommendations}

In this study, the teachers are using the conventional methods to ensure the children understand English. The teachers use translation technique to make the children understand mainly when the teachers are giving instructions. The researcher could barely observe when the teachers are using other techniques to facilitate the interaction between the children. Thus, it is recommended that the teachers could consider other techniques or strategies such as total physical response technique to be used during interaction in English with the children. Both translation and total physical response could be used to facilitate the interaction with the children and thus, enable the children to acquire English.

The selection of the early childhood teachers should be stricter upon the recruitment of preservice teachers. The universities or colleges need to consider the teachers' English proficiency based on their English result in the national exam. The recruitment of the pre-service teachers should be the one who obtain higher grades in English and could interact in English efficiently. 
Furthermore, the stakeholders could prepare a module for the early childhood teachers to teach English through effective interaction with young children. Early childhood teachers can be trained according to the module and it could help the early childhood teachers understand how they could work with children through interaction.

The extensive measures could be taken after this to facilitate the early childhood teachers to teach children through effective interaction. The early childhood teachers can add another strategy in the interaction with children such as using total physical action during interactions. Moreover, the selection of the pre-service teachers needs to be stricter in the aspect of English proficiency than the existing prerequisite due to low English proficiency teacher teaching in early childhood centres. The stakeholders also could provide the early childhood teachers a module to teach English through effective interactions with young children as a guide for them in early childhood setting.

\section{Conclusion}

The teachers need to overcome their dilemma as they find themselves lack of interest and have low self-confidence. These dilemmas are related to the use English and it affects the interaction with the children. There was limited usage of English among teachers. Teachers could use the opportunity to practice using English between colleagues and gain confidence to interact with then children in English. In conclusion, this study has identified the needs of early childhood teachers to interact effectively with young children. This study may be extend to further research to improve the quality of teaching English for young children through effective interaction.

\section{Acknowledgement}

The authors would like to thank the early childhood teachers who are willing to participate in this research. We are also grateful to Sultan Idris Education University \& Ministry of Higher Education for funding this research project.

\section{Corresponding Author}

Siti Hamira Md Ngajib, National Child Development and Research Centre (NCDRC), Sultan Idris Education University (UPSI), Malaysia, hamiramier@gmail.com, No.1, Jalan Nusa 4, Taman Nusa, 35900 Tanjung Malim, Perak, Malaysia.

\section{References}

Bligh, C. (2011). The silent experiences of young bilingual learners: A small scale sociocultural exploration. (Doctoral Dissertation). CREET: The Open University.

Brierley, A. (2003). Including non-English speaking background in our kindergarten programme. Early Education, 3, 3-17.

Chlapana, E. \& Tafa, E. (2014). Effective practices to enhance immigrant kindergarteners? Second language vocabulary learning through storybook reading. Reading and Writing, 27(9), 1619-1640. doi.org/10.1007/s11145-014- 9510-7 
INTERNATIONAL JOURNAL OF ACADEMIC RESEARCH IN BUSINESS AND SOCIAL SCIENCES

Vol. 8, No. 11, Nov, 2018, E-ISSN: 2222-6990 (C) 2018 HRMARS

Chodijah, I. (2008). English in Primary School: Gem in the Mud. Paper presented at the Bangalore Conference 'The Way Forward: Learning from International Experience of TEYL', 3-6 January 2008. Bangalore, India: RIESI

DeVillar, R. A. \& Faltis, C. J. (1991). Computers and cultural diversity: Restructuring for school success. Albany, NY: State University of New York Press.

Dholakia, N. \& Zhang, D. (2004). Forum : Qualitative social research. Online Qualitative Research in the Age of E-Commerce : Data Sources and Approaches 2. Typology of Qualitative E-Commerce

Data Sources. Forum Qualitative Social Research, 5(2), 0-10. Retrieved from http://www.qualitativeresearch.net/index.php/fqs/article/viewArticle/594/1289

Ellis, R. (1999). Learning a second language through interaction. Amsterdam, NL: John Benjamins.

Enever, J., Moon, J. \& Raman, U. (2009). Young learners English language policy and implementation: International perspectives. Garnet Publishing Ltd., 38(3), 504- 506. Retrieved from http://englishagenda.britishcouncil.org/sites/ec/files/books-younglearner-english-language-policy-and-implementation.pdf

Guest, G., MacQueen, K. M. \& Namey, E. E. (2012). Applied thematic analysis. Thousand Oaks, CA: SAGE.

Hazleena, B. \& Abd. Razak, Z. (2013). A qualitative analysis of EFL learners' task generated discourse. Education Journal, 2(6), 242-248. doi.org/10.11648/j.edu.20130206.16

Mackey, A., Abbuhl, R. \& Gass, S. M. (2012). Interactionist approaches. In S. Gass \& A. Mackey (Eds.), The Routledge handbook of second language acquisition (pp. 7-23). New York, NY: Routledge.

Mazlina, C. M. (2015). Supporting Asian immigrant English language learners: Teachers' beliefs and practices. Published doctoral dissertation, University of Canterbury, New Zealand.

Mohd. Sidek, H. (2011). ZPD, scaffolding and syntax development. International Journal of Humanities and Social Science. 1(6), 164-176.

Krashen, S. D. (1982). Principles and practice in second language acquisition. Oxford, UK: Pergamon Press.

Pica, T. (1994). Research on negotiation: What does it reveal about second language learning conditions, processes, and outcomes? Language Learning, 44(3) 493-527. doi: 10.1111/j.1467-1770.1994.tb01115.x 
INTERNATIONAL JOURNAL OF ACADEMIC RESEARCH IN BUSINESS AND SOCIAL SCIENCES

Vol. 8, No. 11, Nov, 2018, E-ISSN: 2222-6990 @ 2018 HRMARS

Tsang, A. (2017). EFL/ ESL teachers' general language proficiency and learners' engagement. RELC Journal, 48(1), 99-113. doi.org/10.1177/0033688217690060

Van Canh, L. \& Renandya, W. A. (2017). Teachers' English Proficiency and Classroom Language Use: A Conversation Analysis Study. RELC Journal, 48(1), 67-81. doi:

$10.1177 / 0033688217690935$

Wang, S. (2015). Key issues in second language acquisition since the 1990s. Theory and Practice in Language Studies, 5(9), 1916. 